\title{
UTILIZATION OF RAW AND AUTOCLAVED WHOLE PODS OF SAMANEA SAMAN (JACQ MERILL) BY THE DOMESTIC RABBIT
}

\author{
O. O.ODUGUWA*, A. O. FANIMO, E. A. ONYEKWERE \\ A. B. OYENUGA AND G. O.SOBOGUN \\ College of Animal Science and Livestock Production, \\ University of Agriculture PMB 2240, Abeokuta, Nigeria.
}

Target Audience: Feed millers, rabbit farmers and researchers.

\section{ABSTRACT}

The utilization of raw and autoclaved whole pods of Samanea saman (SS) by growing rabbits was investigated. The animals were subjected to three dietary treatments containing either $0 \mathrm{~g}$ or $100 \mathrm{~g}$ raw or $100 \mathrm{~g}$ autoclaved whole pods of $\mathrm{SS}$ per $\mathrm{kg}$ diet. Thirty-six growing rabbits were used for the experiment and 12 animals were alloted on weight equalization basis to each of the three dietary treatments. The animals were housed individually in wooden hutches equipped with separate feeders and drinkers. The study lasted for eight weeks during which performance, carcass characteristics and chemical parameters in the blood of the experimental animals were investigated.

The mean final live weights of rabbits confined to the $100 \mathrm{~g} / \mathrm{kg}$ autoclaved SS diets $(1194.2 \mathrm{~g})$ was higher than that of their counterparts fed $100 \mathrm{~g} / \mathrm{kg}$ raw SS diet (1038.0g); so also was the daily feed intake per rabbit. The mean values of these parameters for animals on control diet $(0 \mathrm{~g} / \mathrm{kg}$ SS) and those that were fed the autoclaved SS diet were largely similar. There were no significant differences between the animals on the various treatments for mean values of daily weight gain, feed efficiency and protein efficiency ratio.

No significant difference ( $p>0.05$ ) was observed for the digestibility coefficients of crude protein, crude fibre, ether extract, ash and NFE. Rabbits on the control diet had the highest values of digested calcium and phosphorus.

Although not significantly reduced, the gross features of the blood viz packed cell volume (PCV), Haemoglobin (Hb), red blood cell (RBC), white blood cell (WBC) Mean cell volume (MCV) mean cell haemoglobin (MCH) and mean cell haemoglobin concentration (MCHC), tended to be lower for rabbits fed raw SS pods in their diets. Significantly higher $(p<0.05)$ level of blood urea was also obtained for this same group of rabbits.

The carcass traits showed that there was an enhanced efficiency of tissue laid down and higher carcass yield by animals fed the autoclaved SS pod diets.

It was concluded that SS pods can be included in rabbit diets and autoclaving eliminated the negative effects of antinutritive factors, which appeared to impair proper feed utilization in the raw SS pod diets.

Key words: Raw and autoclaved pods of Samanea saman, domestic rabbit utilization

* Corresponding Author 


\section{DESCRIPTION OF PROBLEM}

Rain tree, formerly known as Pithecelobium saman (Jacq), and now called Samanea saman is called by several conventional names-algarrobo, monkey pod and French tamarind and belongs to the sub family of mimosoideae. It produces pods (fruits) with edible pulp. When ripe, the pulp is sweet and sugary with flavour that is like chocolate. It is valued on pasture farms where it shades the livestock, showering down nutritious pods and fostering the growth of nearby green lush grass (1).

Its growth in Nigeria however has been limited to use as an ornamental shade where its short stem produces wide spreading branches that form massive green foliage crown. The pinkish flowers on the canopy's outer surface have made rain tree a favourite park tree in Ibadan, Benin, Port Harcourt, Oyo, Ogbomoso, Ilorin and other cities and towns in Nigeria.

In spite of the potentials of the rain tree, conscious efforts have not been made to utilize it for livestock feeding. The strain on livestock feed availability and quality posed by seasonal changes can actually be reduced by the use of leguminous tree crops like rain tree as a feed resource. Moreover, rain tree is known to produce and shed its pods at the peak of dry season (2). When ripe, the pods of the rain tree have a crude protein content of between $12-18 \%$ on dry matter basis and a $41 \%$ digestibility by the goat as well as being ravenously consumed by cattle, horses and goats (1).

An envisaged limitation to the use of rain tree and other leguminous crops is the acclaimed presence of toxic factors in their products. D' Mello (3) asserted that these antinutritional factors like protease inhibitors, tannins, saponins, lectins, alkaloids, etc are almost ubiquitous in leguminous plants. He however was quick to add that many of these toxic factors can be removed by simple processing methods like dehulling, soaking, fermentation, heating or treatment with acid, alkali or sodium bicarbonate. It is against this background that the utilization of raw and treated (autoclaved) whole pods of Samanea saman was evaluated as feed resource for rabbits.

\section{MATERIALS AND METHODS}

Ripe and dry whole pods of Samanea saman (SS) were collected during the dry season (December 1995 to February 1996). A portion of the pods was then autoclaved at a temperature of $100^{\circ} \mathrm{C}$ and $50 \mathrm{~kg} / \mathrm{cm}^{2}$ pressure for 15 minutes. The raw and autoclave pods were dried and crushed separately in a hammer mill and representative samples were collected for chemical analysis.

\section{Feeding Trial}

Three isoenergetic diets containing either $0 \mathrm{~g} / \mathrm{kg}$ or $100 \mathrm{~g} / \mathrm{kg}$, autoclaved ground whole pods of SS were formulated (Table 1). The experimental animals were 36 hybrid fryer rabbits with average body weight of $500 \mathrm{~g}$. They were allotted to the three treatment groups each having a total of 12 animals. The animals were housed individually in wooden hutches equipped with separate 
feeders and drinkers. The allotment to treatments was on weight equalization basis.

A 5-day preliminary period was allowed for acclimatization. The animals were fed ad libitum on the experimental diets and given water always. A forage supplement of Tridax procumbens at $50 \mathrm{~g}$ wilted weight per rabbit per day was provided. The experiment ran a course of eight weeks. Records of weekly body weight, feed intake and feed efficiency were taken.

Table 1. Gross and proximate composition of Diets $(\mathrm{g} / \mathrm{kg})$ containing raw and autoclaved whole pods of Samanea saman fed growing rabbits for 8 weeks.

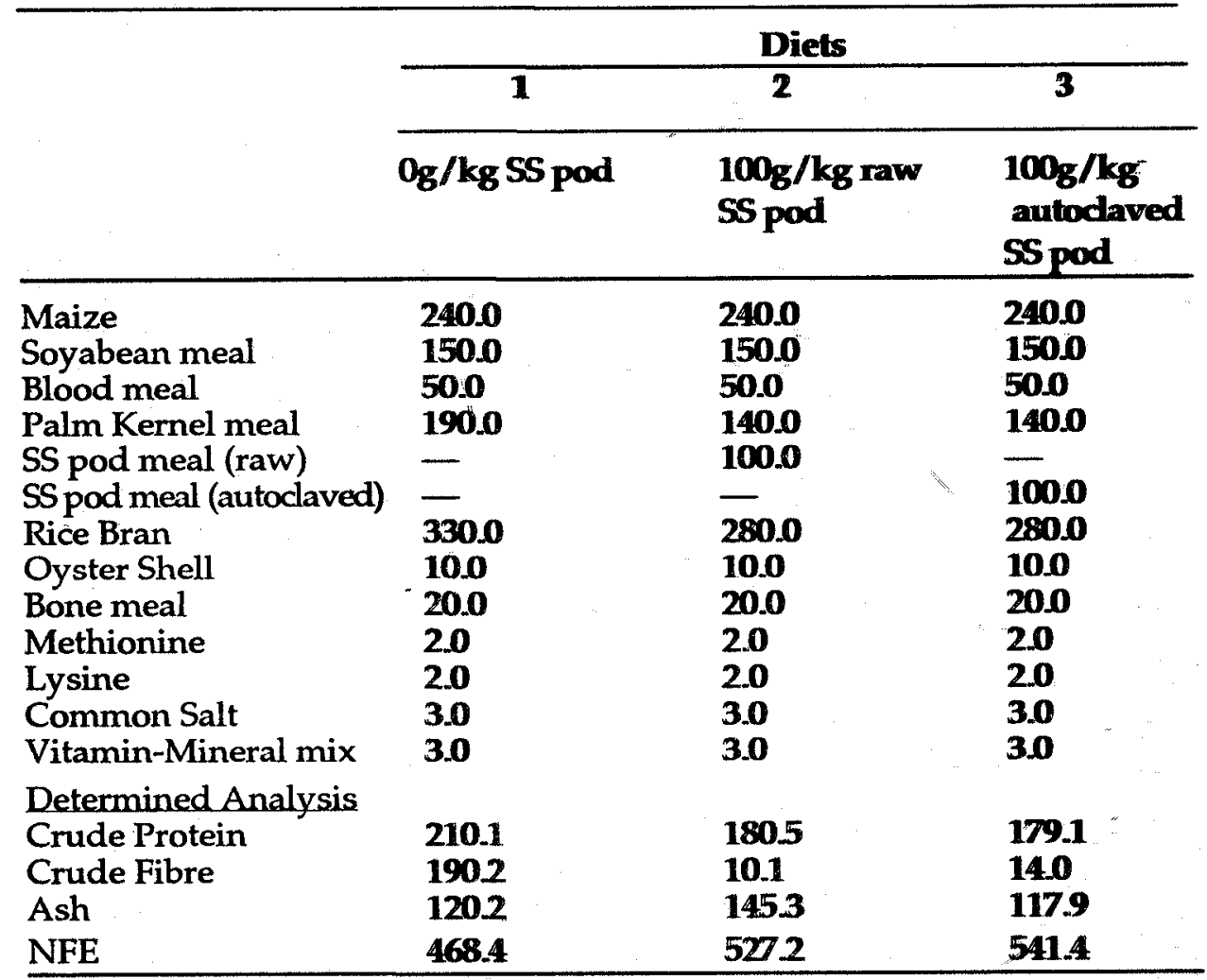

Digestibility Trials

Three groups of 12 hybrid rabbits averaging $1100 \mathrm{~g}$ were used to determine the digestibility of $\mathrm{Ca}, \mathrm{P}$ and the proximate fraction of the diets. A 5-day preliminary period was left for acdimatization of the animals which were housed individually.

During the trial, the rabbits were fed known weights of their respective experimental diets once daily at 08:00hr. Water was provided ad libitum.

The faecal collection lasted 7 days. The collection was done about 06:00hr in the morning before feeding with a polythene sheet which had been spread under each cage. The faeces were collected and weighed once daily and each 
sample was then placed on an aluminium foil and dried in an oven at $80^{\circ} \mathrm{C}$ for $48 \mathrm{hrs}$. The samples were later ground through a $0.1 \mathrm{~mm}$ screen and then stored for analysis.

\section{Chemical Analysis}

The diets and the feed samples were analysed by AOAC methods (4) on dry matter basis for their proximate fractions viz crude protein, crude fibre, ether extract and ash. Calcium was determined by using the flame photometer and phosphorous was assayed according to AOAC methods. (5)

\section{Blood Analysis}

Three rabbits from each experimental diet which had body weights close to average weight of all the animals in the treatment were chosen. The animals were stunned with a sharp knife in the neck region. Blood samples were then collected for each animal. Samples for serum analysis were decanted after centrifugation, while EDTA was added to samples for whole blood analyses. Parameters determined from whole blood are packed cell volume (pcv), haemoglobin $(\mathrm{Hb})$ red blood cell $(\mathrm{RBC})$, white blood cell $(\mathrm{WBC})$, mean cell volume (MVC), mean cell haemoglobin $(\mathrm{MCH})$ and mean cell haemoglobin concentration (MCHC).

\section{Carcass Traits Measurement}

Prior to slaughtering, the sampled animals were denied feed and water overnight. They were thereafter bled, scalded using hot water, evicerated and cut into pieces. The weights of the cut parts viz hind and fore limbs, lumbar region, thoracic region breast and the sacral region were determined by using a sensitive scale, so also were the weights of the liver, kidneys, heart and lungs. The dressed weights and dressing percentages were also determined.

\section{Statistical Analysis}

The data collected were subjected to Analysis of variance (ANOVA) using the mixed model least-squares and maximum likelihood computer program PC - 2 of Harveys (6).

\section{RESULTS AND DISCUSSION}

The proximate compositions for diet 1 (control), diet 2 ( $100 \mathrm{~g} / \mathrm{kg}$ raw SS) and diet $3(100 \mathrm{~g} / \mathrm{kg}$ autoclaved SS) are as shown in Table 1 . The crude protein content ranged from 179.1 to $210.1 \mathrm{~g} / \mathrm{kg}$ which is within the requirement for growing rabbits (7). The high crude fibre level obtained for the control diet $(190.2 \mathrm{~g} / \mathrm{kg})$ compared to those of $137.0 \mathrm{~g} / \mathrm{kg}$ and $147.6 \mathrm{~g} / \mathrm{kg}$ for diets 2 and 3 respectively, was probably due to the high levels of some fibrous feed ingredients (palm kernel meal and rice bran) in its composition. Rabbits require some amount of fibre in their diets to prevent enteritis (8). The level of crude fibre in the diets was adequate as workers $(9,10)$ have recommended about $14 \%$ for growing rabbits. The crude protein value of the raw SS pods in this study $(139.4 \mathrm{~g} / \mathrm{kg})$ Table 2) was fairly low compared to the $12-18 \%$ earlier reported (1). 
Table $2 \mathrm{Ca}, \mathrm{P}$ and proximate composition of raw and autoclaved whole pods of SS ( $\mathrm{gkg}^{-1}$ dry matter)

\begin{tabular}{lll}
\hline & Raw SS Pod & Autoclaved SS Pod \\
\hline Crude Protein & 139.4 & 129.9 \\
Crude fibre & 102.0 & 98.2 \\
Ether Extract & 10.1 & 98.1 \\
Ash & 87.4 & 95.5 \\
NFE & 661.1 & 673.3 \\
Ca & 8.7 & ND \\
P & 0.75 & ND \\
\hline
\end{tabular}

ND $=$ Not determined

The raw whole pods of SS were observed to have slightly higher values of crude protein, crude fibre and ether extract than the autoclaved samples while the latter had higher values of NFE and ash. The difference can largely be attributed to the effect of autoclaving.

Table 3 presents the performance of rabbits on the various treatments, the digestibility coefficients of calcium, phosphorous and the promixate constituents of the experimental diets. The animals were started with initial body weights of about 495.23 . At the end of the experiment, those animals confined to the $100 \mathrm{~g} / \mathrm{kg}$ autoclaved SS diet had a mean body weight of $1194.2 \mathrm{~g}$. This was higher than the mean weight of the group of rabbits that received the raw pods of SS $(1088.0 \mathrm{~g})$. The weight however was not significantly higher than those rabbits that were fed the control diet $(1100.0 \mathrm{~g})$. The fact that rabbits on diet 3 had higher final weights than those on diet 2 showed that the former was nutritionally balanced, which points to the fact that the antinutritional factors which might have been introduced as a result of the inclusion of SS pod had been removed or reduced considerably. D'Mello (1992) (3) observed that many of the antinutritive factors in legumes can be easily neutralised by simple processing methods like dehulling, milling away the seed coat, soaking, heating, fermentation, etc. The heat treatment employed here was effective and it may be possible for the rabbits to tolerate higher inclusion levels of this autoclaved SS pods in their diets.

Rabbits that had $100 \mathrm{~g} / \mathrm{kg}$ autoclaved SS pods in their diets ate more than those that had diets which contained $100 \mathrm{~g} / \mathrm{kg}$ raw pods. The different treatments did not produce significant effects on the values for feed efficiency, daily weight gain and protein efficiency ration. The inclusion of raw SS pods no doubt had a depressing effect on the feed intake and indeed the 
Table 3: Performance characteristics of experimental rabbits and the digestibility coefficients of $\mathrm{Ca}, \mathrm{P}$ and the proximate constituents of the experimental diets $(\mathrm{g} / \mathrm{kg})$

\begin{tabular}{|c|c|c|c|}
\hline \multirow[b]{3}{*}{ Parameters } & \multicolumn{3}{|c|}{ Diets } \\
\hline & 1 & 2 & 3 \\
\hline & $\begin{array}{l}\text { Control } \\
0 \mathrm{~g} / \mathrm{kg} \text { SS } \\
\text { pods }\end{array}$ & $\begin{array}{l}100 \mathrm{~g} / \mathrm{kg} \\
\text { Raw SS } \\
\text { pods }\end{array}$ & $\begin{array}{l}100 \mathrm{~g} / \mathrm{kg} \\
\text { autoclaved } \\
\text { SS pods }\end{array}$ \\
\hline Initial weight $g /$ rabbit & 491.0 & 491.7 & 503.0 \\
\hline Final weight $\mathrm{g} / \mathrm{rabbit}$ & $1100.0^{\mathrm{ab}}$ & $1088.0^{\mathrm{b}}$ & $1194.2^{\mathrm{a}}$ \\
\hline Daily feed intake $\mathrm{g} / \mathrm{rabbit}$ & $56.1^{\mathrm{ab}}$ & $52.5^{\mathrm{b}}$ & $58.8^{\mathrm{a}}$ \\
\hline Daily weight gain $g /$ rabbit & 12.2 & 1.0 & 12.7 \\
\hline Feed effiiciency & 0.26 & 0.19 & 0.21 \\
\hline Protein efficiency ratio & 1.1 & 1.1 & 1.2 \\
\hline Dry Matter Digestibility & 580.7 & 570.4 & 643.6 \\
\hline Crude Protein Digestibility & 788.8 & 720.3 & 778.0 \\
\hline Crude Fibre Digestibility & 580.6 & 570.7 & 640.9 \\
\hline Ether Extract Digestibility & 580.8 & 573.8 & 647.5 \\
\hline Ash & 580.5 & 750.6 & 643.5 \\
\hline NFE & 580.6 & 554.6 & 643.6 \\
\hline $\mathrm{Ca}$ & $857.0^{\mathrm{a}}$ & $786.5^{b}$ & $594.9^{c}$ \\
\hline$\underline{\mathbf{P}}$ & $647.8^{\mathrm{a}}$ & $86.2^{c}$ & $131.8^{b}$ \\
\hline
\end{tabular}

Means on the same row having different superscripts were significantly different $(p<0.05)$

performance. The effect was not significant for the above parameters probably because the inclusion of SS was not high and the level of antinutritional factors introduced was also minimal.

No significant differences were observed for the digestibility coefficients of crude protein, crude fibre, ether extract, ash and NFE. Of all the proximate constituents, the rabbits utilized most the crude protein fractions of the feed. Rabbits on the control diet had the highest values of digested calcium and phosphorus. There were strong indications that the inclusion of SS pods impaired the digestibility of phosphorus, the effect being greater on the rabbits fed diets that contained the raw pod.

Table 4 summarises the haematological parameters and the serum metabolites of the experimental animals. The differences in the gross feature of the blood measured (PCV, HB, RBC, WBC, MCV, MCH and MCHV) were not significant. However, although not significantly reduced, the above parameters (except for $\mathrm{MCV}, \mathrm{MCH}$ and $\mathrm{MCHC}$ which were about the same values for the treatments) tended to be lower for rabbits fed the raw SS pod in 
their diets. This is suggestive of haemolytic factor in raw SS.

The value of serum total protein, its albumin and globulin fractions for the animals fed the various diets were not significatly different. Serum albumin concentration is not a very sensitive index of protein adequacy. Drop in serum albumin of the blood was observed only after prolonged period of protein inadequacy (11). Rabbits that were fed raw SS pod had higher $(p<0.05)$ levels of urea in their blood.

\section{Table 4: Haematological parameters and serum metabolites of rabbits fed raw or autoclaved SŚ pod diets}

\begin{tabular}{|c|c|c|c|}
\hline \multirow[b]{3}{*}{ Parameters } & \multicolumn{3}{|c|}{ Diets } \\
\hline & 1 & 2 & 3 \\
\hline & $\begin{array}{l}0 \mathrm{~g} / \mathrm{kg} \\
\text { SS pods }\end{array}$ & $\begin{array}{l}100 \mathrm{~g} / \mathrm{kg} \\
\text { Raw SS pods }\end{array}$ & $\begin{array}{l}100 \mathrm{~g} / \mathrm{kg} \\
\text { autoclaved SS pods }\end{array}$ \\
\hline PCV $(\%)$ & 43.0 & 39.3 & 43.7 \\
\hline $\mathrm{Hb}(\mathrm{g} / \mathrm{dl})$ & 14.4 & 13.1 & 14.2 \\
\hline RBC (Cell / million) & 4.9 & 4.5 & 4.9 \\
\hline WBC (cell / mm $\left.\mathrm{mm}^{3}\right)$ & 6000.0 & 5933.3 & 6133.3 \\
\hline MCV (cubic microns) & 88.0 & 88.0 & 88.0 \\
\hline $\mathrm{MCH}(/ \mathrm{g})$ & 29.3 & 29.7 & 29.0 \\
\hline MCHC (\%) & 33.3 & 33.0 & 33.0 \\
\hline Serum Albumin (g/dl) & 2.5 & 2.7 & 2.5 \\
\hline Serum Globulin $(g / d)$ & 1.5 & 1.5 & 1.5 \\
\hline Serum Total protein $(\mathrm{g} / \mathrm{dl})$ & 4.0 & 4.2 & 4.0 \\
\hline Serum Urea $(g / d l)$ & $20.0^{\mathrm{b}}$ & $25.0^{\mathrm{a}}$ & $21.0^{\mathrm{b}}$ \\
\hline
\end{tabular}

Means on the same row having differnt superscripts were significantly different $(p<0.05)$

PCV = Packed Cell volume; $\quad H b=$ Haemoglobin; $\quad$ RBC = Red Bood Cell; $\mathrm{WBC}=$ White Blood Cell; $\mathrm{MCV}=$ Mean Cell volume;

$\mathrm{MCH}=$ Mean Cell Haemoglobin; $\mathrm{MCHC}=$ Mean cell haemoglobin concentration

Three factors influence blood urea concentration, quality and quantity of protein in the diet and the time of sampling after feeding (11). These three factors were more or less similar in the dietary treatments except the quality of the protein mixture. The high blood urea levels of rabbits that received raw SS diet indicated a lowered utilization of the protein which probably was due to the presence of one or more antinutritional factors in the raw SS. A high negative correlation was obtained between the biological value of dietary protein and blood urea concentration (12).

Table 5 presents the carcass characteristics and relative organ weights of the experimental animals. Rabbits fed the autoclaved SS pod diets had higher dressing percentage and higher relative weights of breast and thoracic region. The relative weights of fore limbs, hind limbs, lumbar and the sacral region did not differ significantly between the treatments. Rabbits that received the 
raw SS pod diets had significantly lower weights of the heart, kidney and lungs. The enhanced efficiency of tissue laid down and carcass yield of the animals on autoclaved SS pod diet over those that were fed raw SS pod diet is not in doubt. The dressing percentage values obtained in this study agree with that reported by Dennis. (13).

Table 5: Carcass characteristics and Relative Organ Weights of rabbits fed raw or autoclaved SS pod diets (g/100g live weight)

\begin{tabular}{llll}
\hline & \multicolumn{3}{c}{ Diets } \\
\cline { 2 - 4 } & 1 & 2 & 3 \\
\cline { 2 - 4 } & $0 \mathrm{~g} / \mathrm{kg}$ & $100 \mathrm{~g} / \mathrm{kg}$ & $100 \mathrm{~g} / \mathrm{kg}$ \\
Parameters & $\mathrm{SS}$ pods & Raw SS pods & autoclaved SS pods \\
\hline Carcass Traits & & & \\
Fore limbs & 9.2 & 8.3 & 9.4 \\
Hind limbs & 16.0 & 14.5 & 15.8 \\
Thoracic region & $5.1^{\mathrm{b}}$ & $5.2^{\mathrm{ab}}$ & $6.1^{\mathrm{a}}$ \\
Breast & $1.4^{\mathrm{b}}$ & $1.2^{\mathrm{c}}$ & $1.8^{\mathrm{a}}$ \\
Lumbar region & 12.0 & 12.1 & 11.9 \\
Sacral region & 5.1 & 5.1 & 5.3 \\
Dressing percentage & $55.8^{\mathrm{b}}$ & $52.5^{\mathrm{c}}$ & $59.0^{\mathrm{a}}$ \\
Organ Weights & & & \\
Liver & 2.6 & $2.7^{\mathrm{a}}$ & 3.2 \\
Kidneys & $0.68^{\mathrm{b}}$ & $0.38^{\mathrm{c}}$ & $0.91^{\mathrm{a}}$ \\
Heart & 0.30 & $0.22^{\mathrm{c}}$ & $0.28^{\mathrm{b}}$ \\
Lungs & $0.57^{\mathrm{b}}$ & $0.26^{\mathrm{c}}$ & $0.65^{\mathrm{a}}$ \\
Spleen & 0.22 & 0.20 & 0.25 \\
\hline
\end{tabular}

Means on the same row having differnt superscripts were significantly different $(\mathrm{p}<0.05)$

\section{CONCLUSIONS AND APPLICATIONS}

The conclusions from the foregoing therefore are as follows:

(1) Pods of SS can be included in rabbit diets

(2) There are evidences that raw SS contains antinutritional factors which could cause depression in performance of animals

(3) Autoclaving SS pods before incorporation into the diets of rabbits however eliminated the negative effects of the antinutritional factors.

\section{ACKNOWLEDGEMENT}

The authors are grateful to the Research Grants Committee of the Research and Development Centre, University of Agriculture, Abeokuta for financing this project. 


\section{REFEREF'}

1. Nitrogen-Fixing tree association 1987 - NFT t. . . Samanea saman NFTA Highlight NFTA 87 Oct. 6, 1987

2. Aribodo, S. O.1998. Intake and digestiblity of rain tree (Samanea samarg) pods jacq. Merill bu white Fulani calves. M.Sc. project report submitted to the Department of Animal Science, University of Ibadan, Nigeria.

3. D'Mello, J. P. F. 1992. Chemical constraints to the use of tropical legumes in animal nutrition. Amnim. Feed. Sci. Tech. 38:273 - 261.

4. A. O. A. C. 1990 . Official method of analyses $15^{\text {th }}$ Edition. Association of Analytical Chemists Washington D. C.

5. A. O. A. C. 1984. Official methods of analyses $11^{\text {th }}$ Edition Association of Analytical Chemists Washington D. C.

6. Harveys W. R. 1990. LSMLMW - PC 2 version: Mixed Model least squares and maximum likelihood computer program. Dept., of Diary Science, Ohio State Univ. Columbus, Ohio.

7. NRC 1977. Nutrient requrements of domestic animals. No. 9: Nutrient requrements of rabbits $2^{\text {nd }}$ Edition. National Academy of Science Washington D.C.

8. Cheeke, P. R. and N.M. Palton 1980. Carbohydrate overload of the hind gut - a probable cause of enteritis J. Appl. Rabbit Res. 3 (3): 20-23.

9. Lang, J. 1981. The nutrition of the commercial Rabbit. Part I and II in Nutrition Abstracts and reviews, series 13 April/May 51 (4/5).

10. Lebas F. C., Rainer, P. and Rochambean, H. 1986. The rabbit: Husbandry health and production FAO. Animal Production and Health Series No. 21, Rome, PP. 235. 